\title{
Antioxidant Activity and Lipoxygenase Inhibitory Effect of Caralluma arabica and Related Polyphenolic Constituents
}

\author{
Mohammad Khasawneh ${ }^{1}$, Hanan Mohamed Elwy², Nael Mohamed Fawzi ${ }^{3}$, \\ Alaaeldin Ahmed Hamza², Abdul Raheem Chevidenkandy ${ }^{4}$, Ahmed H. Hassan ${ }^{4}$ \\ ${ }^{1}$ Department of Chemistry, UAE University, Al-Ain, UAE \\ ${ }^{2}$ National organization of Drug Control and Research, Giza, Egypt \\ ${ }^{3}$ Flora \& Phyto-Taxonomy Research Department, Agricultural Research Center, Giza, Egypt \\ ${ }^{4}$ Department of Biochemistry, FMHS, UAE University, Al-Ain, UAE \\ Email: ${ }^{\text {mohammad.khasawneh@uaeu.ac.ae }}$
}

Received 25 March 2014; revised 24 April 2014; accepted 6 May 2014

Copyright (C) 2014 by authors and Scientific Research Publishing Inc.

This work is licensed under the Creative Commons Attribution International License (CC BY). http://creativecommons.org/licenses/by/4.0/

c) (i) Open Access

\begin{abstract}
Phytochemicals have been of great interest as a source of natural antioxidants used for health promotion, food preservation, food flavoring and cosmetics. In this research, alcoholic extract from Caralluma arabica and different solvent fractions were evaluated for their antioxidant, anti-inflammatory and anti-cancer properties as well as their polyphenolic compositions. The total antioxidant property was estimated by the ferric reducing antioxidant power (FRAP), 1,1-diphenyl-2-picrylhydrazyl (DPPH), 2, 2-azino-bis(3-ethylbenzothiazoline-6-sulfonate) (ABTS+) and B-carotene bleaching tests. Among the ethanol extract and three fractions, the ethyl acetate fraction showed the highest phenolic content $(33.1 \mathrm{mg}$ gallic acid/g) and the best antioxidant activity. The ascorbic acid equivalent antioxidant capacities of the ethyl acetate fraction were 143.64, 381.3, $112.6 \mu \mathrm{mol} / \mathrm{g}$ in FRAP, ABTS and DPPH assays, respectively. This study verified that the ethanol extract and ethyl acetate fraction from Caralluma arabica have strong antioxidant activity that was correlated with their high level of phenolic content. Furthermore, the same extract showed appreciable anti-inflammatory via Lipoxygenase inhibitory activity (LOX), the $\mathrm{IC}_{50}$ values ranged from 11.2 - $30.77 \mu \mathrm{g} / \mathrm{mL}$. Moreover, Ethyl acetate fraction showed the strongest cytotoxic effect $\left(\mathrm{IC}_{50}=87.55 \mu \mathrm{g} / \mathrm{mL}\right.$ ) against MCF-7 breast cancer cell line. These findings suggest that Caralluma arabica may be considered as an interesting source of antioxidants for nutraceutical industries.
\end{abstract}

\section{Keywords}

Caralluma arabica, Antioxidants, Anticancer, MTT Assay

\footnotetext{
${ }^{*}$ Corresponding author.
}

How to cite this paper: Khasawneh, M., et al. (2014) Antioxidant Activity and Lipoxygenase Inhibitory Effect of Caralluma arabica and Related Polyphenolic Constituents. American Journal of Plant Sciences, 5, 1623-1631. 


\section{Introduction}

There is an increasing interest in the measurement and use of plant antioxidant to medicinal plants with antioxidant properties for scientific research as well as industrial purposes [1]. These healthy protective effects attributed mostly to their polyphenolic components, mainly flavonoids and phenolic acids, which possess antioxidant activity against the reactive oxygen species (ROS) [1] [2]. The nutraceutical value and the antioxidant activity of wild plants are regarded worldwide as an important area of the phytotherapeutic research [3]. Caralluma species (family of Asclepiadaceae) have been used in semi-arid areas of Africa, South-Asian, Middle East and UAE as emergency foods where they are harvested from the wild [3] [4]. Caralluma arabica is known for its anti-inflammatory properties [5]. Caralluma species have shown anti-diabetic [6] [7] and anti-ulcer properties [8]. The photochemistry of the genus Caralluma is characterized by many pregnane glycosides and some of which showed anti-tumor activity [9].

Extracts of Caralluma species are nowadays the object of an increasing interest for antioxidant activity and phytochemical investigation of the middle polar and polar polyphenolic fractions of Caralluma arabica could be worthwhile, in order to find a correlation between the antioxidant and the phytochemistry of this plant. This study is concentrated at the determination of the phenolic content, antioxidant, anti-lipoxygenase and anticancer activities of the aqueous ethanolic extract of Caralluma arabica and its different partition subfractions. The antioxidant potential was evaluated in relation to the scavenging of two stable nitrogen-centered radicals, 1,1-diphenyl-2-picrylhydrazyl (DPPH) and 2, 2-azino-bis(3-ethylbenzothiazoline-6-sulfonate) radical (ABTS+). The reducing power of antioxidants was also evaluated by ferric reducing antioxidant power (FRAP) assay as well as anti-bleaching of ß-carotene activity. The anti-inflammatory effect via Lipoxygenase inhibitory activity of all extracts was also examined. The cytotoxicity of a plant extracts was evaluated using the MTT (3-(4, 5-dimethylthiazol-2-yl)-2,5-diphenylformazan) assay on MCF-7 breast cancer cell line.

\section{Materials and Methods}

\section{1) Chemicals}

Ascorbic acid, ferric chloride, Folin-Ciocalteu reagent, dibutyl hydroxytoluene (BHT), 2,4,6-tripyridyl triazine, gallic acid, sodium carbonate, 1,1-diphenyl-2-picrylhydrazyl (DPPH) and 2,4,6-tripyridyl triazine, 2, 2-azino-bis(3-ethylbenzothiazoline-6-sulfonate) (ABTS) and ß-carotene were obtained from Sigma Chemical Co. (St. Louis, MO, USA). All other chemicals were obtained from common commercial suppliers.

\section{2) Plant Material}

Caralluma arabica was collected in March 2013, from Falaj Hazza area in the town of Al Ain in the southern part of the United Arab Emirates. The harvested specimens were properly identified and voucher specimens were deposited at the Herbarium of the Biology department, Faculty of Science, UAE University.

\section{3) Preparation of Plant Extract}

A sample of ground air-dried aerial part of Caralluma arabica $(10 \mathrm{~g})$ was macerated with $200 \mathrm{~mL}$ of $80 \%$ $(\mathrm{v} / \mathrm{v})$ aqueous ethanol for 72 hours at $4^{\circ} \mathrm{C}$. The resulting mixture was then filtered and divided into two parts. The first part was evaporated to dryness under reduced pressure in a rotary evaporator at $40^{\circ} \mathrm{C}$ to give ethanol crude extract. The other part was concentrated under reduced pressure and was suspended in water to give a volume of $50 \mathrm{~mL}$. The resulting mixture was extracted with n-hexane $(2 \times 100 \mathrm{~mL})$ to remove fatty materials. The aqueous residual layer was extracted sequentially with ethyl acetate, n-butanol using the same protocol was. The crude ethanol extract as well as the four fractions (n-hexane, ethyl acetate, n-butanol and aqueous residue) were dried, weighed, dissolved in DMSO and kept at $-20^{\circ} \mathrm{C}$ for further studies.

\section{4) Determination of Total Phenolic Contents}

Total phenolic contents were determined by the method of Singleton et al. [10] using the Folin-Ciocalteu reagent. For a typical plant extract or fraction obtained a sample $(100 \mu \mathrm{L})$ was mixed with Folin-Ciocalteu reagent $(200 \mu \mathrm{L})$ and de-ionized water $(2 \mathrm{~mL})$ and incubated at room temperature for $3 \mathrm{~min}$. Following incubation, a sample of aqueous sodium carbonate $(20 \% \mathrm{w} / \mathrm{w}, 1 \mathrm{~mL})$ was added to the mixture. The total polyphenols were determined after one hour of incubation at room temperature. The absorbance of the resulting blue color was measured at $765 \mathrm{~nm}$ with a Shimadzu recording spectrophotometer (UV-160). Results were expressed in milligrams of gallic acid equivalent per g dry weight of plant material. Data presented are average of three measurements. 


\subsection{Estimation of Total Antioxidant Activity}

\section{1) FRAP Assay}

FRAP assay was determined according to the method described by Nenadis et al. [11]. This assay is based on the reducing power of antioxidants in which a potential antioxidant reduces the oxidized ferric ions to produce ferrous ions, which form a blue colored complex with tripyridyl triazine. The FRAP reagent was freshly prepared by mixing 2,4,6-tripyridyl triazine $(10 \mathrm{mM}, 1 \mathrm{~mL})$ and ferric chloride $(20 \mathrm{mM}, 1 \mathrm{~mL})$ in $0.25 \mathrm{M}$ acetate buffer $(10 \mathrm{~mL}, \mathrm{pH} 3.6)$. Plant extract sample $(50 \mu \mathrm{L})$ was added to the FRAP reagent ( $3 \mathrm{~mL})$ and the absorbance was measured at $593 \mathrm{~nm}$ after 8 min incubation at room temperature. A calibration curve of ascorbic acid was established, the antioxidant capacity of the plant extracts was then expressed as mmol ascorbic acid equivalent/g dry extract. All measurements were carried out in triplicates.

\section{2) ABTS Assay}

This assay is based on the reduction of the blue-green 2, 2-azino-bis(3-ethylbenzothiazoline-6-sulfonate) radical cation (ABTS+) by antioxidants to its colorless ABTS form according to a method described in [12]. The reaction mixture contained ABTS $(10 \mathrm{mmol})$, hydrogen peroxide $(28.3 \mu \mathrm{mol})$ in acetic acid-sodium acetate buffer (30 mmol, $\mathrm{pH} 3.6$ ) in a total volume of $2 \mathrm{~mL}$. This mixture was rapidly mixed with the plant extract or standard compound $(100 \mu \mathrm{L})$ in a test tube. The contents of the tube were swirled and allowed to stand for 6 minutes and absorbance was then measured at $660 \mathrm{~nm}$. Dibutyl hydroxytoluene (BHT) was used as a positive standard. Inhibition of free radical scavenging activity was calculated using the following equation:

$\%$ Inhibition $=100 \times($ absorbance of the control - absorbance of the sample $) /$ absorbance of the control.

$\mathrm{EC}_{50}$ value $(\mu \mathrm{g} / \mathrm{mL})$ is the effective concentration at which ABTS + are scavenged by $50 \%$ and is determined graphically. A calibration curve of ascorbic acid was established, the antioxidant capacity of the plant extracts was then expressed as mmol ascorbic acid equivalent/g dry extract.

\section{3) DPPH Assay}

The ability of a compound to donate a hydrogen atom was assessed on the basis of the scavenging activity of the stable 1,1-diphenyl-2-picrylhydrazyl (DPPH) radical according to a procedure based on [11]. Methanolic solution of DPPH $(3.8 \mathrm{~mL}, 60 \mu \mathrm{g} / \mathrm{mL})$ was rapidly mixed with the plant extract $(200 \mu \mathrm{L})$ in a test tube. BHT was used as a positive standard. The contents of the tube were swirled and allowed to stand for 30 minutes and absorbance was measured at $517 \mathrm{~nm}$. Inhibition of free radical scavenging activity was calculated using the following equation:

$\%$ Inhibition $=100 \times($ absorbance of the control - absorbance of the sample $) /$ absorbance of the control.

$\mathrm{EC}_{50}$ value $(\mu \mathrm{g} / \mathrm{mL})$ is the effective concentration at which DPPH radicals are scavenged by $50 \%$ and is determined graphically. A calibration curve of ascorbic acid was established and the antioxidant capacity of the plant extracts was then expressed as mmol ascorbic acid equivalent/g dry extract.

\section{4) B-Carotene Bleaching Assay}

The ability of Caralluma arabica extract to prevent bleaching of ß-carotene was assessed according to a procedure based on [13]. ß-carotene solution sample ( $1 \mathrm{~mL}, 200 \mu \mathrm{g} / \mathrm{mL}$ in chloroform) was mixed with linoleic acid $(200 \mu \mathrm{L})$ and Tween $20(200 \mu \mathrm{L})$. The mixture was evaporated to remove chloroform in a rotary evaporator at $40^{\circ} \mathrm{C}$. Immediately, de-ionized water $(100 \mathrm{~mL})$ was added slowly to form an emulsion. Aliquots of the ß-carotene/linoleic acid emulsion (3 $\mathrm{mL}$ each) were mixed in a series of test tubes containing plant extracts (200 $\mu \mathrm{L}$ each). An aqueous methanol solution $(200 \mu \mathrm{L}$ of $50 \% \mathrm{v} / \mathrm{v})$ in $3 \mathrm{~mL}$ of the above emulsion was used as a control and BHT was used as a positive standard. After incubation of the samples, standards and control at $45^{\circ} \mathrm{C}$ for $120 \mathrm{~min}$, the absorbance was measured at $470 \mathrm{~nm}$. Inhibition of free radical scavenging activity was calculated using the following equation:

$$
\% \text { Inhibition }=1-\frac{(\text { absorbance of the control after zero time }- \text { absorbance of the control after } 120 \mathrm{~min})}{(\text { absorbance of the sample after zero time }- \text { absorbance of the sample120 min })} \times 100 \text {. }
$$

$\mathrm{EC}_{50}$ value $(\mu \mathrm{g} / \mathrm{mL})$ is the effective concentration at which bleaching of ß-carotene is prevented by $50 \%$.

\section{5) Lipoxygenase Inhibition Assay}

Lipoxygenase (EC 1.13.11.12 type 1-B) (LOX) was assayed according to the method described by Wu [14]. 
A mixture of sodium borate buffer $(1 \mathrm{ml}, 0.1 \mathrm{M}, \mathrm{pH} 8.8)$ and soybean LOX solution (10 $\mu \mathrm{L}$, final conc. 8000 $\mathrm{U} / \mathrm{mL})$ was incubated with plant extract sample $(10 \mu \mathrm{L})$ in a $1 \mathrm{~mL}$ cuvette at room temperature for $5 \mathrm{~min}$. The reaction was started by the addition of linolic acid substrate $(10 \mu \mathrm{L}, 10 \mathrm{mmol})$. The absorbance was measured at 1 min time intervals for $3 \mathrm{~min}$ at $234 \mathrm{~nm}$. Nordihydroguaiaretic acid (NDGA) was used as positive standard. Inhibition of LOX was calculated using the following equation:

$\%$ Inhibition $=100 \times($ absorbance of the control - absorbance of the sample $) /$ absorbance of the control.

$\mathrm{IC}_{50}$ value $(\mu \mathrm{g} / \mathrm{mL})$ is the effective concentration at which LOX activity is inhibited by $50 \%$ and is determined graphically.

\subsection{Cytotoxicity}

The cytotoxicity of Caralluma arabica extracts was evaluated using the MTT (3-(4,5-dimethylthiazol-2-yl)-2, 5-diphenylformazan) assay on MCF-7 human breast cancer cell line model. Cells were grown in the DMEM medium (GIBCO-BRL) supplemented with 10\% fetal calf serum (GIBCO-BRL, USA), 100 units/ml penicillin-streptomycin (GIBCO-BRL, USA) and non-essential amino acid (GIBCO-BRL, USA). The cells were maintained at $37^{\circ} \mathrm{C}$ in $5 \% \mathrm{CO}_{2}$ incubator. After reaching confluency, the cells were sub cultured into 96 wells culture plates, allowed to grow for $1-2$ days to a density of $2 \times 10^{4}$ cells/well and treated with different concentrations of CA extracts (final concentrations $10-500 \mu \mathrm{g} / \mathrm{mL}$ in $0.05 \%$ DMSO) for 24 hours. MTT solution with DMSO served as a negative control and with SDS as a positive control. The MTT [3-(4,5-dimethylthiazol-2-yl)2-5-diphenyltetrazolium bromide] assay was performed according to the manufacturer (Promega, USA) instructions to examine the cytotoxic effect of these compounds. Briefly, $20 \mu \mathrm{L}$ of MTT reagent (Cell Titer 96-Aquous non-radioactive cell proliferation Assay, Promega, USA) was added to the each well, and incubated the cells for one to two hours. This assay is a colorimetric assay for cell viability based on the cellular cleavage of the yellow tetrazolium salt, MTT, into the purple formazan crystals that is soluble in cell culture medium and is measured at $490 \mathrm{~nm}$ directly in 96-well assay plates. Absorbance is directly proportional to the number of the living cells in culture. Viability was calculated as a percentage of the control cells. All experiments were carried out in triplicates. $\mathrm{The} \mathrm{IC}_{50}$ value was defined as the concentration of plant extract necessary to inhibit the growth to $50 \%$ of the control.

\section{Identification of main polyphenolic compounds}

HPLC analyses were performed according to the method of [15] Abad-Garcia et al. with an Agilent 1200 LC system consisting of degasser, quaternary pump (G1311A), auto sampler (G1329A), column heater (G1316A) and diode array detector (DAD) (G1315C). A reversed phase C18 (4.6 mm $\times 250 \mathrm{~mm} \times 5 \mu \mathrm{m})$ column (Waters Corporation, Milford, MA, USA) was used. The mobile phase used in this study was a gradient of two solvents: solvent A (acetic acid-water, 0.5:99.5, v/v) and B (methanol). The gradient profile was as follows: $0-2 \mathrm{~min}, 0 \%$ B isocratic; 2 - 6 min, linear gradient from 0\% to 15\% B; 6 - 12 min, 15\% B isocratic; 12 - 17 min, linear gradient from $15 \%$ to $20 \%$ B; 17 - 35 min, 20\% B isocratic; 35 - 90 min, linear gradient from 20\% to $35 \%$ B; 90 $136 \mathrm{~min}, 35 \% \mathrm{~B}$ isocratic. After each run, the system was washed and reconditioned for 10 min before analysis of next sample. The flow rate was $0.8 \mathrm{ml} / \mathrm{min}$ and injection volume was $50 \mu \mathrm{L}$. A series of individual standard solutions of polyphenolic compounds (each $1.0 \mathrm{mg} / \mathrm{mL}$ ) dissolved initially in minimal amount of DMSO and diluted with aqueous methanol (50:50 v/v) was used to generate calibration curves. Polyphenolic compounds were identified and quantified in the samples by using retention times and calibration curves, respectively. The detection was carried out at 254, 280, 320 and $370 \mathrm{~nm}$.

\section{Statistical Analysis}

The data are expressed as means \pm SEM. Correlation analysis of antioxidants versus the total phenolic content was carried out using the regression analysis, with SPSS version 10 statistical programs (SPSS Inc., Chicago, IL, USA).

\section{Results and Discussion}

\subsection{Antioxidant and Free Radical Scavenging Activity}

Due to the complex nature of the different phytochemical classes present in plants, the antioxidant capacities of 
plant extracts cannot be evaluated using a single method. In the present work, the FRAP, ABTS, DPPH and ß-carotene methods were used to assess the antioxidant activities of plant extracts.

\subsection{FRAP Assay}

FRAP assay depends on the reduction of ferric ions to the ferrous ions by the antioxidant agents. Table 1 shows that all fractions of Caralluma arabica extract exhibited some degree of electron donation capacity. The ethyl acetate fraction exhibited the highest antioxidant potency (143.64 $\mu \mathrm{mol}$ ascorbic acid equivalent/g) followed by crude ethanol extract ( $89.65 \mu \mathrm{mol}$ ascorbic acid equivalent/g dry extract). The antioxidant potency of the extracts in FRAP assay was in the following order ethyl acetate fraction (143.64) > crude ethanol extract (89.65) > butanol fraction (51.65) > (35.18) water fraction.

\subsection{ABTS Radical Scavenging Assay}

ABTS assay expressed as ascorbic acid equivalent/g dry extract varied from $381.3 \mu \mathrm{mol} / \mathrm{g}$ for ethyl acetate fraction to $210.4 \mu \mathrm{mol} / \mathrm{g}$ extract for water fraction. Ethyl acetate fraction was comparable to the synthetic antioxidant BHT $(420 \mu \mathrm{mol} / \mathrm{g})$. The ethyl acetate fraction showed the strongest activity with $\mathrm{IC}_{50}=88.1 \mu \mathrm{g} / \mathrm{mL}$. The activity of the extracts were in the following order BHT $>$ ethyl acetate fraction $>$ crude ethanol extract $>$ butanol fraction $>$ water fraction (Table 1). The measured ABTS radical scavenging ability of the ethyl acetate fraction of Caralluma arabica is higher than those reported for other plants such as pistachios $(75.9 \mu \mathrm{mol} / \mathrm{g})$ and almonds (25.4 $\mu \mathrm{mol} / \mathrm{g})[16]$.

\subsection{DPPH Radical Scavenging Assay}

The DPPH radical- scavenging assay is a widely used method for evaluating the ability of antioxidants (or plant extracts) to scavenge the stable free radical generated from DPPH, which changes its color from purple into yellow upon accepting a hydrogen radical $\left(\mathrm{H}^{\cdot}\right)$ from the antioxidant species to form the stable DPPH-H molecule [13]. The results of the DPPH assay expressed as ascorbic acid equivalent/g dry extract and as IC $_{50}$ values $(\mu \mathrm{g} / \mathrm{mL})$ for the four fractions of Caralluma arabica extract are shown in table 1. The best free radical scavenging activity was exerted by ethyl acetate fraction $\left(\mathrm{IC}_{50}=314.2 \mu \mathrm{g} / \mathrm{mL}\right.$ ), which contained the highest amount of total phenolic. The lowest radical scavenging activity was exhibited by the water fraction $\left(\mathrm{IC}_{50}=818.5 \mu \mathrm{g} / \mathrm{mL}\right.$ ). The overall trend of the scavenging abilities of the extracts were in the following order BHT $>$ ethyl acetate fraction $>$ crude ethanol extract $>$ butanol fraction $>$ water fraction.

\section{5. ß-Carotene Bleaching Test}

ß-carotene undergoes rapid bleaching in the absence of antioxidants. The presence of antioxidants hinders the extent of bleaching by neutralizing the linolic hydroperoxyl radical formed. The ethyl acetate fraction $\left(\mathrm{IC}_{50}=\right.$ $72.89 \mu \mathrm{g} / \mathrm{mL}$ ) and ethanol extract $\left(\mathrm{IC}_{50}=106.0 \mu \mathrm{g} / \mathrm{mL}\right.$ ) showed the highest ability to prevent bleaching of ß-carotene, followed by butanol fraction ( $\mathrm{IC}_{50}=306.0 \mu \mathrm{g} / \mathrm{mL}$ ) and water fraction $\left(\mathrm{IC}_{50}=110.0 \mu \mathrm{g} / \mathrm{mL}\right.$ ). Inhibition of bleaching of ß-carotene ability of ethyl acetate fraction is much higher than those reported for some other

Table 1. Total antioxidant activity of ethanol extract and soluble fractions from Caralluma arabica. BHT was used as positive control.

\begin{tabular}{|c|c|c|c|c|c|c|c|}
\hline & \multirow[t]{2}{*}{ Extract } & \multirow{2}{*}{$\begin{array}{c}\text { FRAP Assay } \\
\text { TAC }(\mu \mathrm{mol} / \mathrm{g})\end{array}$} & \multicolumn{2}{|c|}{ ABTS Assay } & \multicolumn{2}{|c|}{ DPPH Assay } & \multirow{2}{*}{$\begin{array}{l}\text { ß-Carotene Assay } \\
\text { IC }_{50} \mu \mathrm{g} / \mathrm{mL}\end{array}$} \\
\hline & & & $\mathrm{TAC}(\mu \mathrm{mol} / \mathrm{g})$ & $\mathrm{IC}_{50} \mu \mathrm{g} / \mathrm{mL}$ & TAC $(\mu \mathrm{mol} / \mathrm{g})$ & $\mathrm{IC}_{50} \mu \mathrm{g} / \mathrm{mL}$ & \\
\hline $\mathrm{a}$ & Ethanol Extract & $89.65 \pm 0.65^{b, c, d}$ & $280.2 \pm 0.05^{\mathrm{b}, \mathrm{e}}$ & $116.1 \pm 1.1^{\mathrm{b}, \mathrm{c}, \mathrm{d}}$ & $74.1 \pm 0.01^{\mathrm{c}, \mathrm{d}, \mathrm{e}}$ & $440.7 \pm 20.5^{\mathrm{b}, \mathrm{c}, \mathrm{d}, \mathrm{e}}$ & $106.0 \pm 1.1^{\mathrm{b}, \mathrm{d}, \mathrm{e}}$ \\
\hline $\mathrm{b}$ & Ethyl acetate & $143.64 \pm 0.17^{\mathrm{a}, \mathrm{c}, \mathrm{d}}$ & $381.3 \pm 0.01^{\mathrm{a}, \mathrm{c}, \mathrm{d}}$ & $88.1 \pm 6.1^{\mathrm{a}, \mathrm{c}, \mathrm{d}}$ & $112.6 \pm 0.02^{\mathrm{c}, \mathrm{d}, \mathrm{e}}$ & $314.2 \pm 5.13^{\mathrm{a}, \mathrm{c}, \mathrm{d}, \mathrm{e}}$ & $72.89 \pm 2.9^{\mathrm{a}, \mathrm{c}, \mathrm{d}, \mathrm{e}}$ \\
\hline c & n-Butanol & $51.65 \pm 0.65^{\mathrm{a}, \mathrm{b}, \mathrm{d}}$ & $240.3 \pm 0.01^{\mathrm{b}, \mathrm{e}}$ & $135.00 \pm 5.0^{\mathrm{b}, \mathrm{d}, \mathrm{e}}$ & $34.7 \pm 0.01^{\mathrm{a}, \mathrm{b}, \mathrm{e}}$ & $601.5 \pm 11.5^{\mathrm{a}, \mathrm{b}, \mathrm{d}, \mathrm{e}}$ & $110.0 \pm 1.0^{\mathrm{b}, \mathrm{d}, \mathrm{e}}$ \\
\hline d & Water & $35.18 \pm 0.28^{\mathrm{a}, \mathrm{b}, \mathrm{c}}$ & $210.4 \pm 0.01^{\mathrm{b}, \mathrm{e}}$ & $168.40 \pm 1.78^{\mathrm{a}, \mathrm{b}, \mathrm{c}, \mathrm{e}}$ & $23.5 \pm 0.05^{\mathrm{a}, \mathrm{b}, \mathrm{e}}$ & $818.5 \pm 1.5^{\mathrm{a}, \mathrm{b}, \mathrm{c}, \mathrm{d}}$ & $306.0 \pm 5.0^{\mathrm{a}, \mathrm{b}, \mathrm{c}, \mathrm{e}}$ \\
\hline e & BHT & - & $420.0 \pm 0.01^{\mathrm{a}, \mathrm{c}, \mathrm{d}}$ & $77.85 \pm 0.85^{\mathrm{a}, \mathrm{c}, \mathrm{d}}$ & $430.1 \pm 0.05^{\mathrm{a}, \mathrm{b}, \mathrm{c}, \mathrm{d}}$ & $87.98 \pm 7.70^{\mathrm{a}, \mathrm{b}, \mathrm{c}, \mathrm{d}}$ & $36.85 \pm 1.15^{\mathrm{a}, \mathrm{b}, \mathrm{c}, \mathrm{d}}$ \\
\hline
\end{tabular}

Values are means \pm SE of three experiments. Data with different letters are significantly different $(\mathrm{p}<0.05)$. 
plants such as mint $\left(\mathrm{IC}_{50}>100 \mu \mathrm{g} / \mathrm{mL}\right)$ and radish $\left(\mathrm{IC}_{50}>100 \mu \mathrm{g} / \mathrm{mL}\right)$ and chicory $\left(\mathrm{IC}_{50}>100 \mu \mathrm{g} / \mathrm{mL}\right)$ [17] [18].

\subsection{Total Phenolic Contents}

The total phenolic content of the Caralluma arabica extract was measured with the Folin-Ciocalteu reagent assay and the results are shown in Table 2 . The values varied from 11.46 to $33.1 \mathrm{mg}$ gallic acid/g of dry extract. Ethyl acetate fraction contained the highest amount of phenolics (33.1 mg gallic acid/g), followed by ethanol crude extract (31.5 mg gallic acid/g) and butanol fraction (29.68 mg gallic acid/g), whereas the lowest level was found in the water fraction (11.46 mg gallic acid/g). Total phenolic contents of the ethyl acetate and butanol fractions of Caralluma arabica are higher than those reported for other Caralluma species such as Caralluma quadrangula (18.7 mg gallic acid/g).

\subsection{Correlation between Antioxidant Activity and Phenolic Content}

The correlation coefficient $\left(\mathrm{R}^{2}\right)$ between the antioxidant values and total phenolic content of ethanol extract of the plants and its various fractions was determined (Table 3). The significant linear correlation was confirmed between total phenolic content and related FRAP, DPPH and ABTS and ß-carotene bleaching inhibition antioxidant activities of medicinal plant extracts. Therefore, the presence of phenolic compounds contributed significantly to the antioxidant activity of the tested extracts. This result is in agreement with the previous reports [13] [19].

\subsection{LOX Inhibition Assay}

LOXs are the key enzymes in the biosynthesis of leukotrienes that play an important role in several inflammatory diseases such as arthritis, asthma, cancer and allergic diseases [20]. LOX catalyzes deoxygenating of polyunsaturated fatty acids to yield cis, trans-conjugated diene hydroperoxides. All Caralluma arabica extracts exhibited strong LOX inhibitory activity with $\mathrm{IC}_{50}$ ranging from 11.2 to $30.77 \mu \mathrm{g} / \mathrm{mL}$ (Figure 1). The ethyl acetate fraction $\left(\mathrm{IC}_{50}=11.2 \mu \mathrm{g} / \mathrm{mL}\right)$ and butanol extract $\left(\mathrm{IC}_{50}=15.19 \mu \mathrm{g} / \mathrm{mL}\right)$ showed the highest ability to inhibit LOX activity, followed by water fraction $\left(\mathrm{IC}_{50}=26.37 \mu \mathrm{g} / \mathrm{mL}\right.$ ) and ethanol extract $\left(\mathrm{IC}_{50}=30.77 \mu \mathrm{g} / \mathrm{mL}\right)$. LOX inhibition of Caralluma arabica extracts was higher than that of other plants such as Oregon grape $(761 \mu \mathrm{g} / \mathrm{mL})$ [19]. These results indicate that Caralluma arabica has high anti-inflammatory effect, which can be presumably related to polyphenolic content and antioxidant property of extract.

Table 2. Total phenol content of ethanol extract and soluble fractions from Caralluma arabica expressed as gallic acid equivalents (mg/g of dry extract).

\begin{tabular}{cccc}
\hline & Extract & Yield (\%) & Total Phenolic Content (mg/g) \\
\hline a & ethanol Extract & $8 \%$ & $31.5 \pm 1.17^{\mathrm{b}, \mathrm{c}, \mathrm{d}}$ \\
$\mathrm{b}$ & ethyl acetate & $1.6 \%$ & $33.1 \pm 1.12^{\mathrm{a}, \mathrm{c}, \mathrm{d}}$ \\
$\mathrm{c}$ & n-Butanol & $6.4 \%$ & $29.68 \pm 0.97^{\mathrm{a}, \mathrm{b}, \mathrm{d}}$ \\
$\mathrm{d}$ & water & $6 \%$ & $11.46 \pm 2.28^{\mathrm{a}, \mathrm{b}, \mathrm{c}}$ \\
\hline
\end{tabular}

Values are means \pm SE of three experiments. Data with different letters are significantly different $(\mathrm{p}<0.05)$.

Table 3. Linear correlations between the amount of total phenolic content and antioxidant activity of the ethanol extract and soluble fractions from Caralluma arabica.

\begin{tabular}{ccc}
\hline Assay & Correlation $\mathrm{R}^{2}$ & Significant \\
\hline FRAP activity & 0.773 & $\mathrm{p}<0.01$ \\
ABTS+ scavenging activity & 0.882 & $\mathrm{p}<0.001$ \\
DPPH scavenging activity & 0.5 & $\mathrm{p}<0.05$ \\
B-carotene bleaching inhibition & 0.768 & $\mathrm{p}<0.01$ \\
\hline
\end{tabular}




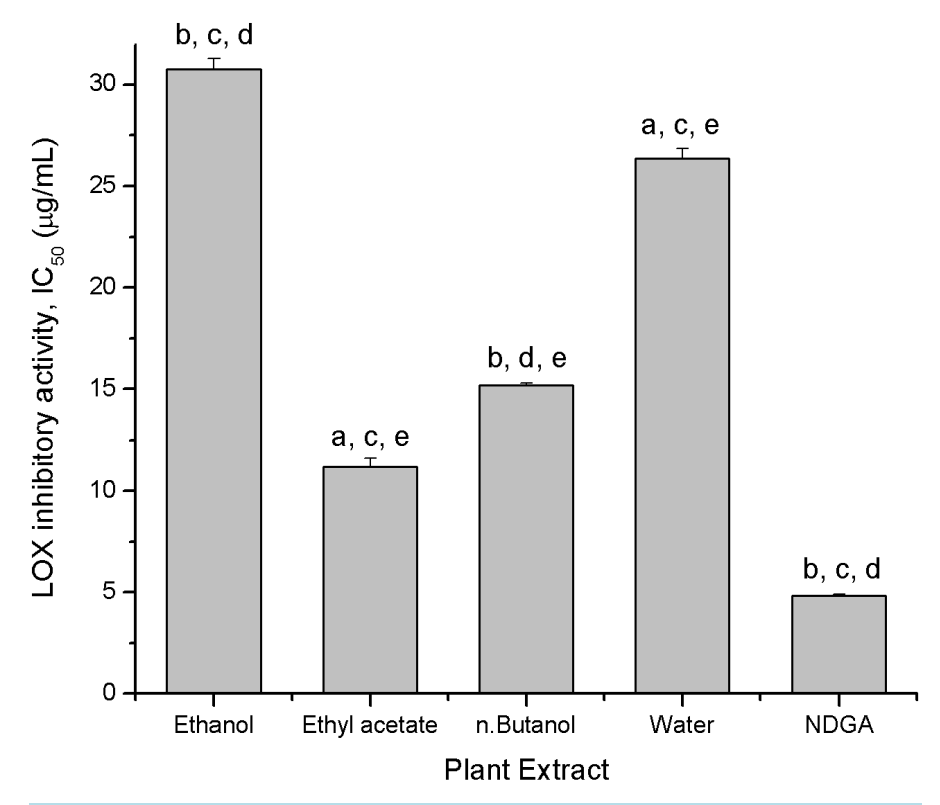

Figure 1. LOX inhibitory activities of ethanol extract and soluble fractions from Caralluma arabica expressed as IC $50(\mu \mathrm{g} / \mathrm{mL})$. Values are means $\pm \mathrm{SE}$ of three experiments. Bars with different letters are significantly different $(\mathrm{p}<0.05)$.

\subsection{Cytotoxicity}

The four Caralluma arabica fractions were evaluated for cytotoxicity activities against MCF-7 breast cancer cell line. Cell growth was measured using the MTT reduction assay procedure. The inhibitory effect of cell growth was observed to be concentration dependent (Figure 2). Ethyl acetate fraction showed strongest cytotoxic effect $\left(\mathrm{IC}_{50}=87.55 \mu \mathrm{g} / \mathrm{mL}\right)$, followed by ethanol crude extract $\left(\mathrm{IC}_{50}=103.33 \mu \mathrm{g} / \mathrm{mL}\right)$ and water fraction $\left(\mathrm{IC}_{50}=385.1 \mu \mathrm{g} / \mathrm{mL}\right)$, whereas the lowest effect was found in butanol fraction $\left(\mathrm{IC}_{50}=927.30 \mu \mathrm{g} / \mathrm{mL}\right)$.

\subsection{Identification of Main Polyphenolic Compounds}

HPLC analysis revealed the presence of various compounds in Caralluma arabica extracts (Table 4). Quantitative and qualitative identification of the various plant extracts were performed against authentic standards of eight possible polyphenolic compounds (gallic acid, vanillic acid, syringic acid, epicatechin, p-coumaric acid, ferulic acid, quercetin-3-ß-D-glucoside and rutin). Ethanol crude extract was found to contain four of these compounds, with gallic acid and quercetin-3-ß-D-glucoside being the highest in concentration (0.38 and 0.79 $\mathrm{mg} / \mathrm{g}$ extract, respectively). On the other hand, the eight previously mentioned polyphenolic compounds were detected in the ethyl acetate fraction, with quercetin-3-ß-D-glucoside, epicatechin and vanillic acid being the highest in concentration (2.43, 1.05 and $0.44 \mathrm{mg} / \mathrm{g}$ extract, respectively). The n-butanol fraction was found to contain gallic acid and quercetin-3-ß-D-glucoside in lower concentrations (0.32 and $0.37 \mathrm{mg} / \mathrm{g}$ extract, respectively) as the major components. Finally, only gallic acid was detected in the water fraction in moderate concentration $(0.48 \mathrm{mg} / \mathrm{g}$, respectively). From these results, it can be seen that the polyphenolic compounds were concentrated in the ethyl acetate fraction as compared with the n-butanol and water fractions. These results may suggest that the antioxidant, anti-inflammatory and anti-cancer properties of Caralluma arabica could be attributed to their polyphenolic compounds and synergistic interactions.

\section{Conclusion}

The investigation of Caralluma arabica alcoholic extract partition fractions yielded promising antioxidant, anti-inflammatory and anti-cancer properties. Generally, ethyl acetate fraction showed the highest activity in all the studied assays. Based on the observed trends obtained in this research, bioactivities were presumably attributed to their polyphenolic compositions. 


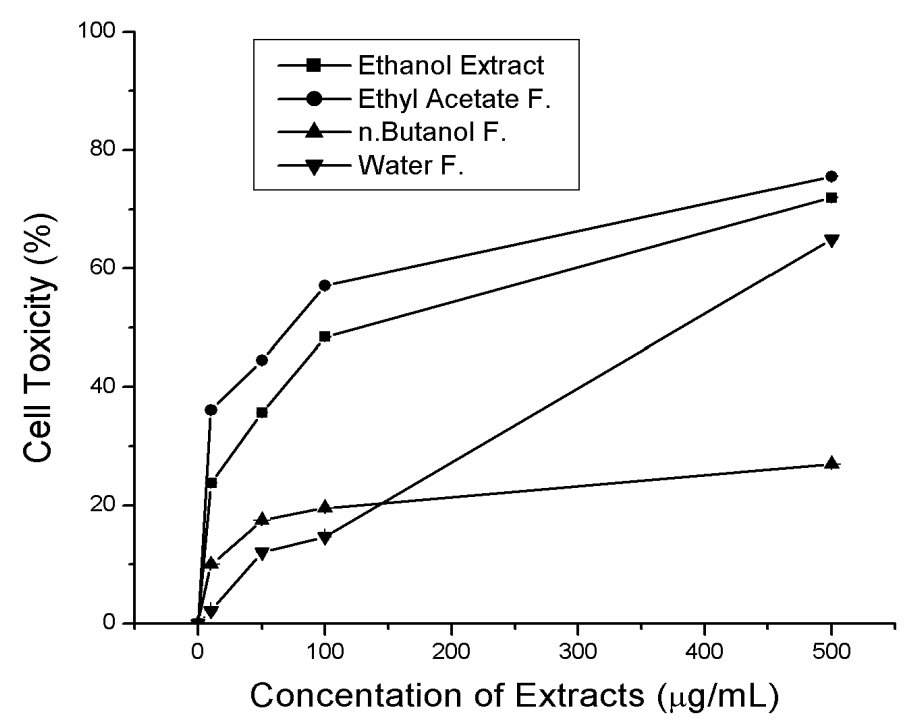

Figure 2. Cytotoxic effect of ethanol extract and soluble fractions from Caralluma arabica on MCF-7 breast cancer cells. Cell toxicity was measured by MTT assay. Data are means of percentage changes of control.

Table 4. Contents of main polyphenolic compounds of ethanol extract and soluble fractions from Caralluma arabica.

\begin{tabular}{cccc}
\hline Extract & Retention time (min) & Compound identified & Contents (mg/g extracts) \\
\hline & $10.45 \pm 0.02$ & Gallic acid & $0.38 \pm 0.03$ \\
Ethanol Extract & $29.41 \pm 0.15$ & Vanillic acid & $0.10 \pm 0.003$ \\
& $90.74 \pm 0.05$ & Quercetin-3ß- $D$-glucoside & $0.79 \pm 0.002$ \\
& $92.90 \pm 0.04$ & Rutin & $0.25 \pm 0.001$ \\
$10.55 \pm 0.01$ & Gallic acid & $0.27 \pm 0.001$ \\
$29.48 \pm 0.02$ & Vanillic acid & $0.44 \pm 0.003$ \\
Ethyl acetate & $34.46 \pm 0.02$ & Syringic acid & $0.03 \pm 0.02$ \\
& $36.23 \pm 0.05$ & --)Epicatechin & $1.05 \pm 0.008$ \\
& $49.98 \pm 0.01$ & p-Coumaric acid & $0.12 \pm 0.002$ \\
& $58.36 \pm 0.03$ & Ferulic acid & $0.15 \pm 0.001$ \\
n-Butanol & $90.62 \pm 0.02$ & Quercetin-3ß- $D$-glucoside & $2.43 \pm 0.009$ \\
Water & $92.98 \pm 0.01$ & Rutin & $0.25 \pm 0.009$ \\
& $10.50 \pm 0.02$ & Gallic acid & $0.32 \pm 0.005$ \\
\hline
\end{tabular}

Values are means $\pm \mathrm{SE}$ of three experiments.

\section{Acknowledgements}

The authors want to thank the office of the vice provost for research and graduate studies at UAEU for financial support of this project (project number 1163-02-02-10).

\section{References}

[1] Williams, R.J., Spencer, J.P.E. and Rice-Evans, C. (2004) Flavonoids and Isoflavones (Phytoestrogens): Absorption, 
Metabolism, and Bioactivity. Flavonoids: Antioxidants or Signalling Molecules? Free Radical Biology and Medicine, 36, 838-849. http://dx.doi.org/10.1016/j.freeradbiomed.2004.01.001

[2] Soobrattee, M.A., Neergheen, V.S., Luximon-Ramma, A., Aruoma, O.I. and Bahorun, T. (2005) Phenolic as Potential Antioxidant Theraputic Agents: Mechanism and Actions. Mutation Research, 579, 200-213.

[3] Ansari, N.M., Houlihan, L. Hussain, B. and Pieroni, A. (2005) Antioxidant Activity of Five Vegetables Traditionally consumed by South-Asian Migrants in Bradford, Yorkshire, UK. Phytopherapy, 19, 907-911.

[4] Marwah, R.G., Fatope, M.O., Mahrooqi, R., Varma, G.B., Al badi, H. and Al-Burtamani, S.K. (2006) Antioxidant Capacity of Some Edible and Wound Healing Plants in Oman. Food chemistry, 101, 465-470. http://dx.doi.org/10.1016/j.foodchem.2006.02.001

[5] Zakaria, M.N.M., Islam, M.W., Radhakrishnan, R., Chen, H.B., Kamil, M., Al-Gifri, A.N., Chan, K. and Al-Attas, A. (2001) Anti-Nociceptive and Anti-Inflammatory Properties of Caralluma arabica. Journal of Ethnopharmacology, 76, 155-158. http://dx.doi.org/10.1016/S0378-8741(01)00208-2

[6] Habibuddin, M., Daghriri, H.A., Humaira, T., Al Qahtani, M.S. and Hefzi, A.A. (2008) Antidiabetic Effect of Alcoholic Extract Caralluma sinaica L. on Streptozotocin-Induced Diabetic Rabbits. Journal of Ethnopharmacology, 117, 215-220. http://dx.doi.org/10.1016/j.jep.2008.01.021

[7] Tatiya, A.U., Kulkarni, A.S., Surana, S.J. and Bari, N.D. (2010) Antioxidant and Hypolipidemic Effect of Caralluma adscendens Roxb. in Alloxanized Diabetic Rats. International Journal of Pharmacology, 6, 400-406. http://dx.doi.org/10.3923/ijp.2010.400.406

[8] Al-harbi, M.D., Quershi, S., Raza, M., Ahmed, M.M., Afzal, M. and Shah, A.H. (1994) Evaluation of Caralluma tuberculata Pretreatment for the Protection of Rat Gastric Mucosa against Toxic Damage. Toxicology and Applied Pharmacology, 128, 1-8. http://dx.doi.org/10.1006/taap.1994.1173

[9] Bader, A., Braca, A., De Tommasi, N. and Morelli, I. (2003) Further Constituents from Caralluma negevensis. Phytopherapy, 62, 1277-1281.

[10] Singleton, V.L., Orthofer, R. and Lamuela-Raventos, R.M. (1999) Analysis of Total Phenols and Other Oxidation Substrates and Antioxidants by Means of Folin-Ciocalteu Reagent. In: Packer, L., Ed., Methods in Enzymology, Academic Press, Harcourt Brace \& Company, San Diego, London, New York, Tokyo, 152-178.

[11] Nenadis, N., Lazaridou, O. and Tsimidou, M.Z. (2007) Use of Reference Compounds in Antioxidant Activity Assessment. Journal of Agriculture and Food Chemistry, 55, 5452-5460. http://dx.doi.org/10.1021/jf070473q

[12] Erel, O. (2004) A Novel Automated Direct Measurement Method for Total Antioxidant Capacity Using a New Generation, More Stable ABTS Radical Cation. Clinic Biochemistry, 37, 277-285. http://dx.doi.org/10.1016/j.clinbiochem.2003.11.015

[13] Lim, Y.Y. and Quah, E.P.L. (2007) Antioxidant Properties of Different Cultivars of Portulaca oleracea. Food Chemistry, 103, 734-740. http://dx.doi.org/10.1016/j.foodchem.2006.09.025

[14] Wu, H. (1996) Affecting the Activity of Soybean Lipoxygenase-1. Journal of Molecular Graphics, 14, 331-337. http://dx.doi.org/10.1016/S0263-7855(97)00006-4

[15] Abad-Garcia, B., Berrueta, L.A., Lopez-Marquez, D.M., Crespo-Ferrer, I., Gallo, B. and Vicente, F. (2007) Optimization and Validation of a Methodology Based on Solvent Extraction and Liquid Chromatography for the Simultaneous Determination of Several Polyphenolic Families in Fruit Juices. Journal of Chromatography, 1154, 87-96. http://dx.doi.org/10.1016/j.chroma.2007.03.023

[16] Yang, J., Hailiu, R. and Halim, L. (2009) Antioxidant and Antiproliferative Activities of Common Edible Nut Seeds. Food Science and Technology, 42, 1-8.

[17] Conforti, F., Sosa, S., Marrelli, M., Menichini, F., Statti, G.A., Uzunov, D., Tubaro, A., Menichini, F. and Loggia, R.L. (2008) In Vivo Anti-Inflammatory and in Vitro Antioxidant Activities of Mediterranean Dietary Plants. Journal of Ethnopharmacology, 116, 144-151. http://dx.doi.org/10.1016/j.jep.2007.11.015

[18] Conforti, F., Sosa, S., Marrelli, M., Menichini, F., Statti, G.A., Uzunov, D., Tubaro, A. and Menichini, F. (2009) The Protective Ability of Mediterrannean Dietary Plants against the Oxidative Damage: The Role of Radical Oxygen Species in Inflammation and the Polyphenol, Flavonoid and Sterol Contents. Food Chemistry, 112, 587-594. http://dx.doi.org/10.1016/j.foodchem.2008.06.013

[19] Wojdylo, A., Oszmianski, J. and Czemerys, R. (2007) Antioxidant Activity and Phenolic Compounds in 32 Selected Herbs. Food Chemistry, 105, 940-949. http://dx.doi.org/10.1016/j.foodchem.2007.04.038

[20] Rackova, L., Oblozinsky, M., Kastalova, D., Kettmann, V. and Bezakova, L. (2007) Free Radical Scavenging Activity and Lipoxygenase Inhibition of Mahonia aquifolium Extract and Isoquinoline Alkaloids. Journal of Inflammation, 4, 1-7. http://dx.doi.org/10.1186/1476-9255-4-15 